\title{
Green Leaf Lettuce Breeding Lines with Resistance to Corky Root, 06-831 and 06-833
}

\author{
Beiquan Mou ${ }^{1}$ \\ U.S. Dept. of Agriculture (USDA), Agricultural Research Service, 1636 East \\ Alisal Street, Salinas, CA 93905
}

Additional index words. Rhizomonas suberifaciens, Sphingomonas suberifaciens, disease resistance, Lactuca sativa, germplasm

Corky root of lettuce (Lactuca sativa L.) has been found in major lettuce-producing regions of the world, including North America, Western Europe, Australia, and New Zealand. Roots of infected plants develop yellow to brown lesions that later become longitudinal corky ridges. Yield losses from reduced head size can reach $30 \%$ to $70 \%$ in severely infested fields in California and Florida (van Bruggen, 1997). The pathogen most commonly isolated from diseased roots is the bacterium Sphingomonas suberifaciens (Yabuuchi et al., 1999), formerly Rhizomonas suberifaciens, although several other bacterial species have also been isolated (van Bruggen, 1997). The incidence of corky root can be reduced by soil fumigation (O'Brien and van Bruggen, 1990) and by using lettuce transplants instead of directseeding (van Bruggen and Rubatzky, 1992). However, these practices may not be economically feasible for the Salinas Valley, CA, the major lettuce production area in the United States (Patterson et al., 1986). The use of cultivars resistant to $S$. suberifaciens has been an important management strategy for corky root. The resistance to corky root is controlled by a recessive allele (cor) at a single locus (Brown and Michelmore,1988), which has been deployed in most resistant lettuce cultivars.

Although corky root resistance has been transferred into many crisphead lettuce cultivars, there are few leaf lettuce varieties with the resistance, especially for publicly released cultivars. With increasing consumption and production of leaf lettuce, there is a need for public germplasm that facilitates the research and development of new cultivars and germplasm. In this article, we describe two green leaf breeding lines with resistance to corky root and adaptation to the major lettuce production areas of the central coast of California.

\footnotetext{
Received for publication 20 June 2011. Accepted for publication 10 July 2011.

This research was supported in part by grants from the California Leafy Greens Research Program.

The technical assistance of JoAnn Tanaka and Sharon Benzen is greatly appreciated.

USDA is an equal opportunity provider and employer. ${ }^{1}$ To whom reprint requests should be addressed; e-mail beiquan.mou@ars.usda.gov.
}

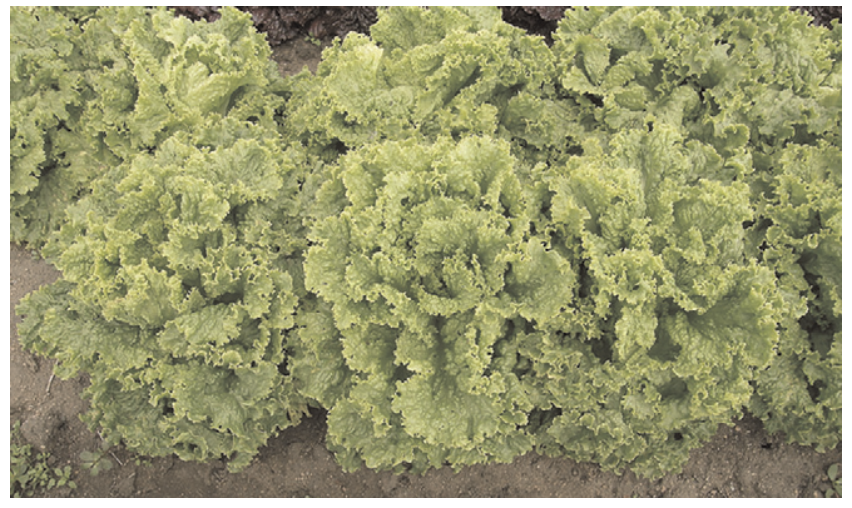

Fig. 1. Green leaf lettuce 06-831 in the field.

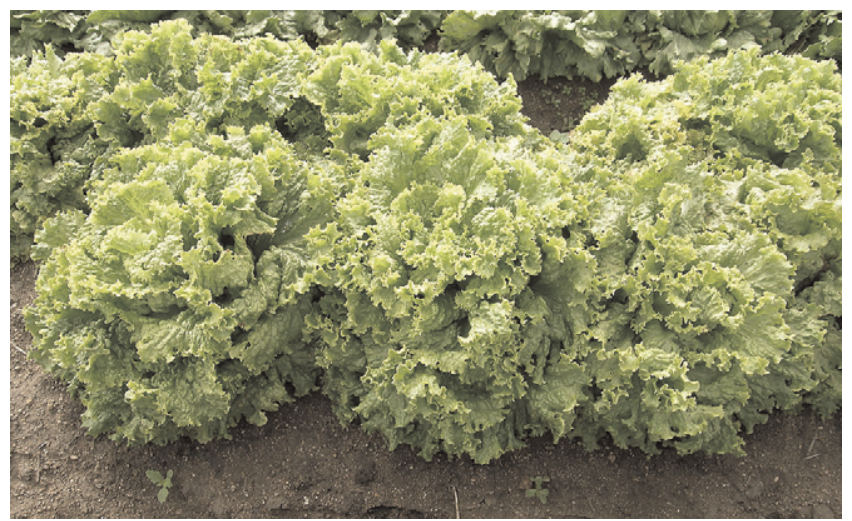

Fig. 2. Green leaf lettuce 06-833 in the field.

Table 1. Means of corky root rating for leaf lettuce breeding lines and cultivars grown in trials from 2007 to 2010 at Spence Farm, Salinas, CA.

\begin{tabular}{llllll}
\hline & & \multicolumn{4}{c}{ Corky root $^{\text {z,y }}$} \\
\cline { 3 - 6 } Genotype & Type & 2007 & 2008 & 2009 & 2010 \\
\hline Waldman's Green & Green leaf & $8.0 \mathrm{a}$ & $8.0 \mathrm{a}$ & $8.0 \mathrm{a}$ & $7.9 \mathrm{ab}$ \\
Shining Star & Green leaf & $7.9 \mathrm{ab}$ & $8.0 \mathrm{a}$ & $7.9 \mathrm{ab}$ & $7.9 \mathrm{ab}$ \\
Two Star & Green leaf & $7.8 \mathrm{ab}$ & $7.9 \mathrm{a}$ & $7.7 \mathrm{~b}$ & $7.4 \mathrm{bc}$ \\
Lolla Rossa & Red leaf & $7.7 \mathrm{abc}$ & $7.8 \mathrm{a}$ & $7.1 \mathrm{c}$ & $7.2 \mathrm{c}$ \\
Big Red & Red leaf & $7.5 \mathrm{bc}$ & $7.9 \mathrm{a}$ & $7.8 \mathrm{ab}$ & $7.8 \mathrm{ab}$ \\
Redina & Red leaf & $7.2 \mathrm{~cd}$ & $6.9 \mathrm{~b}$ & $6.7 \mathrm{c}$ & $7.2 \mathrm{c}$ \\
Merlot & Red leaf & $6.8 \mathrm{~d}$ & $6.7 \mathrm{~b}$ & $7.2 \mathrm{bc}$ & $6.9 \mathrm{c}$ \\
Grand Rapids & Green leaf & - & $8.0 \mathrm{a}$ & $8.0 \mathrm{a}$ & $8.0 \mathrm{a}$ \\
Prizehead & Red leaf & - & $7.9 \mathrm{a}$ & $7.9 \mathrm{a}$ & $7.8 \mathrm{ab}$ \\
Glacier & Crisphead & $5.4 \mathrm{e}$ & $5.9 \mathrm{c}$ & $5.7 \mathrm{~d}$ & $5.7 \mathrm{~d}$ \\
06-831 & Green leaf & $5.7 \mathrm{e}$ & $5.6 \mathrm{c}$ & $5.9 \mathrm{~d}$ & $5.6 \mathrm{~d}$ \\
$06-833$ & Green leaf & $5.3 \mathrm{e}$ & $5.4 \mathrm{c}$ & $5.4 \mathrm{e}$ & $5.5 \mathrm{~d}$ \\
\hline
\end{tabular}

${ }^{z}$ Corky root ratings using Brown and Michelmore's (1988) scale of 0 to 9.

${ }^{\mathrm{y}}$ Means with the same letter are not significantly different at $P<0.05$. Plot means were analyzed by analysis of variance using the general linear model procedure of JMP Version 5 (SAS Institute, Cary, NC). Genotype was considered the fixed effect and replication was considered the random effect. 
Table 2. Means of plant weight (g), core length (cm), and tipburn for leaf lettuce breeding lines and cultivars grown in trials from 2007 to 2010 at Spence Farm, Salinas, CA.

\begin{tabular}{|c|c|c|c|c|c|c|c|c|c|c|c|c|}
\hline \multirow[b]{2}{*}{ Genotype } & \multicolumn{3}{|c|}{2007} & \multicolumn{3}{|c|}{2008} & \multicolumn{3}{|c|}{2009} & \multicolumn{3}{|c|}{2010} \\
\hline & $\begin{array}{l}\text { Plant wt } \\
(\mathrm{g})^{\mathrm{z}}\end{array}$ & $\begin{array}{l}\text { Core } \\
(\mathrm{cm})^{\mathrm{y}}\end{array}$ & $\begin{array}{l}\text { Tipburn } \\
\text { leaves }\end{array}$ & $\begin{array}{c}\text { Plant wt } \\
\text { (g) }\end{array}$ & $\begin{array}{l}\text { Core } \\
(\mathrm{cm})\end{array}$ & $\begin{array}{l}\text { Tipburn } \\
\text { leaves }\end{array}$ & $\begin{array}{l}\text { Plant wt } \\
(\mathrm{g})\end{array}$ & $\begin{array}{l}\text { Core } \\
(\mathrm{cm})\end{array}$ & $\begin{array}{l}\text { Tipburn } \\
\text { leaves }\end{array}$ & $\begin{array}{l}\text { Plant wt } \\
(\mathrm{g})\end{array}$ & $\begin{array}{l}\text { Core } \\
(\mathrm{cm})\end{array}$ & $\begin{array}{c}\text { Tipburn } \\
\text { leaves }\end{array}$ \\
\hline Waldman's Green & $565.0 \mathrm{bcd}$ & $8.9 \mathrm{a}$ & $0.0 \mathrm{~b}$ & $526.3 \mathrm{de}$ & $9.1 \mathrm{bc}$ & $0.0 \mathrm{~b}$ & $393.7 \mathrm{c}$ & $9.1 \mathrm{ab}$ & $0.3 \mathrm{ab}$ & $285.3 \mathrm{~cd}$ & $4.2 \mathrm{def}$ & $0.7 \mathrm{a}$ \\
\hline Shining Star & $477.3 \mathrm{de}$ & $5.2 \mathrm{bc}$ & $0.0 \mathrm{~b}$ & $690.8 \mathrm{c}$ & 7.6 cde & $0.0 \mathrm{~b}$ & $448.3 \mathrm{bc}$ & $7.2 \mathrm{bc}$ & $0.3 \mathrm{ab}$ & $399.0 \mathrm{bc}$ & $5.7 \mathrm{~cd}$ & $0.1 \mathrm{a}$ \\
\hline Two Star & $559.3 \mathrm{~cd}$ & $4.5 \mathrm{c}$ & $0.0 \mathrm{~b}$ & $736.3 \mathrm{bc}$ & $4.8 \mathrm{~g}$ & $0.0 \mathrm{~b}$ & $449.4 \mathrm{bc}$ & $5.1 \mathrm{~cd}$ & $0.0 \mathrm{~b}$ & $348.3 \mathrm{bc}$ & $4.4 \mathrm{def}$ & $0.1 \mathrm{a}$ \\
\hline Lolla Rossa & $149.0 \mathrm{~g}$ & $5.6 \mathrm{bc}$ & $0.0 \mathrm{~b}$ & $217.5 \mathrm{~g}$ & 7.2 cdef & $0.0 \mathrm{~b}$ & $110.7 \mathrm{e}$ & $2.6 \mathrm{e}$ & $0.0 \mathrm{~b}$ & $86.1 \mathrm{~d}$ & $3.3 \mathrm{f}$ & $0.0 \mathrm{a}$ \\
\hline Big Red & $505.8 \mathrm{de}$ & $8.8 \mathrm{a}$ & $0.0 \mathrm{~b}$ & $806.8 \mathrm{abc}$ & $13.2 \mathrm{a}$ & $4.0 \mathrm{a}$ & $333.7 \mathrm{~cd}$ & $5.0 \mathrm{cde}$ & $0.5 \mathrm{ab}$ & $462.1 \mathrm{bc}$ & $8.3 \mathrm{ab}$ & $0.0 \mathrm{a}$ \\
\hline Redina & $235.5 \mathrm{f}$ & $7.8 \mathrm{a}$ & $0.0 \mathrm{~b}$ & 357.0 ef & $10.6 \mathrm{~b}$ & $0.0 \mathrm{~b}$ & $306.2 \mathrm{~cd}$ & $11.2 \mathrm{a}$ & $0.0 \mathrm{~b}$ & $276.0 \mathrm{~cd}$ & $8.4 \mathrm{a}$ & $0.0 \mathrm{a}$ \\
\hline Merlot & $244.3 \mathrm{f}$ & $5.4 \mathrm{bc}$ & $0.0 \mathrm{~b}$ & $326.8 \mathrm{fg}$ & $8.8 \mathrm{bc}$ & $0.0 \mathrm{~b}$ & $257.7 \mathrm{de}$ & $4.3 \mathrm{de}$ & $0.0 \mathrm{~b}$ & $276.2 \mathrm{~cd}$ & $6.5 \mathrm{bc}$ & $0.0 \mathrm{a}$ \\
\hline Grand Rapids & - & - & - & $421.5 \mathrm{de}$ & $5.0 \mathrm{fg}$ & $0.0 \mathrm{~b}$ & $320.5 \mathrm{~cd}$ & 4.9 cde & $0.5 \mathrm{ab}$ & $336.8 \mathrm{bc}$ & $5.2 \mathrm{cde}$ & $0.8 \mathrm{a}$ \\
\hline Prizehead & - & - & - & $690.5 \mathrm{c}$ & 5.9 defg & $0.0 \mathrm{~b}$ & $374.5 \mathrm{~cd}$ & $4.3 \mathrm{de}$ & $0.3 \mathrm{ab}$ & $289.0 \mathrm{~cd}$ & 3.4 ef & $0.0 \mathrm{a}$ \\
\hline Glacier & $654.3 \mathrm{abc}$ & $4.3 \mathrm{c}$ & $0.5 \mathrm{a}$ & $796.5 \mathrm{abc}$ & $5.1 \mathrm{fg}$ & $0.6 \mathrm{~b}$ & $622.4 \mathrm{a}$ & $4.4 \mathrm{de}$ & $0.1 \mathrm{~b}$ & $809.7 \mathrm{a}$ & $6.5 \mathrm{bc}$ & $0.0 \mathrm{a}$ \\
\hline $06-831$ & $688.8 \mathrm{a}$ & $5.8 \mathrm{bc}$ & $0.0 \mathrm{~b}$ & $924.5 \mathrm{a}$ & $8.2 \mathrm{bcd}$ & $0.4 \mathrm{~b}$ & $602.2 \mathrm{ab}$ & $6.8 \mathrm{bc}$ & $0.0 \mathrm{~b}$ & $530.3 \mathrm{~b}$ & $6.0 \mathrm{~cd}$ & $0.8 \mathrm{a}$ \\
\hline $06-833$ & $665.5 \mathrm{ab}$ & $5.9 \mathrm{bc}$ & $0.0 \mathrm{~b}$ & $851.5 \mathrm{ab}$ & 7.4 cdef & $0.0 \mathrm{~b}$ & $641.3 \mathrm{a}$ & $7.9 \mathrm{~b}$ & $1.3 \mathrm{a}$ & $519.8 \mathrm{~b}$ & $6.5 \mathrm{bc}$ & $0.3 \mathrm{a}$ \\
\hline
\end{tabular}

${ }^{\mathrm{z}}$ Means with the same letter are not significantly different at $P<0.05$.

${ }^{y}$ Core length from bottom of the plant.

${ }^{\mathrm{x}}$ Number of leaves with tipburn per plant.

\section{Description}

The lines 06-831 and 06-833 look similar to 'Waldmann's Green' and related cultivars (Figs. 1 and 2). The green color extends close to the core. Leaf margins are mildly incised, indented, and undulated. The leaf surface is crinkled or blistered. Leaf width and length are approximately equal, but the leaf becomes narrower toward the base. Ribs are flat but become more pointed toward the base. Bases of outer and interior leaves overlap well. The texture is relatively soft and flexible. It has a mild and slightly sweet taste. Seed color is black.

\section{Disease Resistance}

The breeding lines, along with nine commercial leaf lettuce cultivars, were planted in trials at the Spence Farm of the Agricultural Research Service of the USDA, Salinas, CA, in the past 4 years with the following planting dates: 19 June 2007, 10 June 2008, 9 June 2009, and 16 June 2010. Cultivar Glacier was included in all trials as a resistant control. The experimental design was a randomized complete block with four replications. Each plot was $14 \mathrm{~m}$ long at the commercial spacing of $30 \mathrm{~cm}$ between plants and $35 \mathrm{~cm}$ between rows on a 1-m-wide double-row bed. Standard production practices were followed in these trials. At harvest maturity, the roots of three randomly selected plants from each plot were rated using Brown and Michelmore's (1988) scale of 0 to 9 (0, no disease symptom; 9, plant died from the disease). The corky root ratings of the breeding lines were not significantly different from the resistant control 'Glacier' but were significantly lower than nine susceptible leaf lettuce cultivars in the trials (Table 1).

From field observations, the breeding lines were not resistant to downy mildew (Bremia lactucae Regel, data not shown). Other disease reactions have not been tested.

\section{Performance and Adaptation}

In the field trials mentioned, three randomly selected plants from each plot were cut at ground level and weighed. The heads were then cut open to measure core length and core diameter at the base. The number of leaves with tipburn disorder in each head was also noted.

The plant weight of the breeding lines was generally higher than other leaf lettuce cultivars (Table 2). The core length of the breeding lines was similar or shorter than the cultivars. A short core length is generally preferred by most lettuce processors. The tipburn leaves of the breeding lines were comparable to most commercial cultivars.

In the limited trials, the breeding lines performed well in the Salinas Valley, producing a high percentage of plants of adequate size, shape, and uniformity. The adaptation of these breeding lines to other lettuce-growing areas has not been evaluated.

\section{Seed Availability}

Limited samples of seed are available from the author for distribution to all interested parties for research purposes, including the develop- ment and commercialization of new cultivars. Samples will also be deposited in the National Plant Germplasm System. It is requested that appropriate recognition be made if the breeding lines contribute to research or the development of new germplasm, breeding lines, or cultivars.

\section{Literature Cited}

Brown, P.R. and R.W. Michelmore. 1988. The genetics of corky root resistance in lettuce. Phytopathology 78:1145-1150.

O’Brien, R.D. and A.H.C. van Bruggen. 1990. Soil fumigation with dazomet and methyl bromide for control of corky root of iceberg lettuce. Plant Dis. 74:1022-1025.

Patterson, C.L., R.G. Grogan, and R.N. Campbell. 1986. Economically important diseases of lettuce. Plant Dis. 70:982-987.

Ryder, E.J. and W. Waycott. 1994. Crisphead lettuce resistant to corky root: Cultivars Glacier and Misty Day and 16 resistant breeding lines. HortScience 29:335-336.

van Bruggen, A.H.C. 1997. Corky root, p. 28-29. In: R.M. Davis, K.V. Subbarao, R.N. Raid and E.A. Kurtz (eds.). Compendium of lettuce diseases. APS Press, St. Paul, MN.

van Bruggen, A.H.C. and V.E. Rubatzky. 1992. Use of transplants instead of direct seeding to reduce corky root severity and losses due to corky root in iceberg lettuce. Plant Dis. 76:703-708.

Yabuuchi, E., Y. Kosako, T. Naka, S. Suzuki, and I. Yano. 1999. Proposal of Sphingomonas suberifaciens (van Bruggen, Jochimsen, and Brown 1990) comb. Nov., sphingomonas natatoria (Sly 1985) cob. Nov., Sphingomonas ursincola (Yurkov et al. 1997) comb. Nov., and emendation of the genus Sphingomonas. Microbiol. Immunol. 43:339-349. 